\begin{abstract}
By exploiting the information in a panel data set, this paper is able to construct more powerful tests of various hypotheses on the determinants of real exchange rates than would be possible with single-country time-series data. Focusing on annual data for 20 industrial countries from 1973 through 1995, there are three major results. First, the evidence for a stationary real exchange rate is stronger when the exchange rate is defined in terms of wholesale prices than consumer prices, presumably because of the greater tradability of wholesale commodities. Second, the half-life of shocks to the real exchange rate is between two and three years. Third, there is a significant and robust relationship between real exchange rates and net foreign assets.
\end{abstract}




\title{
Net Foreign Assets and Equilibrium Exchange Rates: Panel Evidence
}

\author{
Joseph E. Gagnon ${ }^{1}$
}

\section{Introduction and Summary}

This paper exploits a panel of annual data for 20 countries from 1960 through 1995 to examine the relationships between real exchange rates and a number of variables that have been proposed in the literature on exchange rate determination. These variables are the level of net foreign assets, the ratio of consumer prices to wholesale prices, the level of real per capita income, and the share of government consumption in total output. The panel cointegration approach used in this paper estimates long-run equilibrium relationships while controlling for simultaneity and feedback from the exchange rate to the explanatory variables.

Real per capita income does not have any statistically significant relationship with the real exchange rate either in the short run or in the long run. Government consumption also does not have any long-run relationship with the real exchange rate, but the future change in government spending does have a robust short-run effect. When government consumption is expected to increase in the following year,

\footnotetext{
${ }^{1}$ Senior Economist in the International Finance Division of the Board of Governors of the Federal Reserve System. This work was performed in part while I was a special advisor at the U.S. Department of the Treasury. I am deeply indebted to Andrew Rose, with whom I began this project, and to Andrew Levin for panel cointegration advice. I would also like to thank David Bowman, Menzie Chinn, Dale Henderson, Graciela Kaminsky, Mico Loretan, Catherine Mann, Jaime Marquez, and John Rogers for helpful comments. This paper represents the views of the author and should not be interpreted as reflecting those of the Board of Governors of the Federal Reserve System, the U.S. Department of the Treasury, or other members of their staffs.
} 
the real exchange rate appreciates temporarily. The CPI-WPI ratio is strongly correlated with the real exchange rate defined in terms of CPIs, but it has only a weak long-run correlation with the WPI real exchange rate. This finding supports the view that CPIs contain a significant component of nontradable goods and services prices that are not arbitraged by international trade. The level of net foreign assets is significantly and robustly correlated with the real exchange rate, both in the short run and the long run.

Focusing on the relationship between the WPI real exchange rate and net foreign assets, the estimates indicate that the half-life of real exchange rate disequilibria is about two and one-half years. For most countries in the sample, net foreign assets are essentially constant, and the real exchange fluctuates widely with no trend. For a few countries, net foreign assets have a pronounced trend. It is primarily for these countries that the real exchange rate appears to drift over time.

\section{Literature Review}

Following the econometric methodology of Levin and Lin (1992), a number of researchers recently have tested for stationarity of the real exchange rate using panel data, including Frankel and Rose (1996), Papell (forthcoming), and Wei and Parsley (1995). These studies typically claim to reject the hypothesis of a unit root in the real exchange rate using the greater power of panel data. However, O'Connell (1996) shows that the standard practice of defining all exchange rates relative to a single country can distort the size of the test, and that correcting for this effect weakens the 
evidence against a unit root. This paper extends the panel framework to control for the O'Connell critique and to consider cointegration between the real exchange rate and other variables.

The literature on the determinants of the real exchange rate is too voluminous for an exhaustive review, especially as Froot and Rogoff (1995) and Rogoff (1996) provide up-to-date surveys. Dornbusch and Fischer (1980), Hooper and Morton (1982), and Gavin (1991) present theoretical treatments of the relationship between net foreign assets and the exchange rate that form the basis for this study. Hooper and Morton develop a model in which exogenous shocks to trade flows create a longrun positive correlation between net foreign assets and the real exchange rate (defined as the price of home goods relative to foreign goods). In a more complete theoretical model, Gavin shows that exogenous shocks to wealth create a positive correlation between net foreign assets and the real exchange rate when the MarshallLerner condition is satisfied. ${ }^{2}$ Hooper and Morton (1982), Faruqee (1995), and Obstfeld and Rogoff (1995) present empirical results confirming a positive correlation between net foreign assets and the real exchange rate.

In a more general framework, both net foreign assets and the real exchange rate should be viewed as endogenous variables that influence each other and are determined simultaneously. The papers cited above focus on the effects of exogenous

${ }^{2}$ The same shocks create a negative correlation when the Marshall-Lerner condition does not hold. The Marshall-Lerner condition is that the price elasticity of demand for tradables should be sufficiently high that a real depreciation leads to an increase in the trade balance. Nearly all econometric estimates of trade elasticities satisfy this condition, at least in the long run. See Marquez (1990). 
shocks that affect net foreign assets directly. The transmission to the real exchange rate is based on the conclusion that in equilibrium, a country with negative net foreign assets must have a trade surplus to finance the stream of interest and dividend payments. The mechanism to generate this trade surplus is a real exchange rate depreciation. Similarly, countries with positive net foreign assets must have trade deficits in equilibrium. Thus, a shock to net foreign assets has a long-run effect on the real exchange rate as long as goods produced in different countries are not perfect substitutes.

While shocks to the real exchange rate have a well-defined short-run effect on net foreign assets, their long-run effect is ambiguous. Such shocks have no effect on net foreign assets unless they affect a country's saving rate permanently. In some simple models of trade and asset accumulation, exchange rate shocks have no longrun effect on net foreign assets, and net foreign asset shocks do have a long-run effect on the real exchange rate.

It is important to recognize that exchange rate dynamics may be the mechanism by which shocks to desired net foreign assets are equilibrated. Thus, an increase in desired net foreign assets may cause an immediate depreciation of the exchange rate in order to generate a trade surplus, followed by a long-run real appreciation of the exchange rate above its initial level once the desired net foreign asset stock is achieved.

Balassa (1964) and Samuelson (1964) argued that technological progress is biased toward the production of tradables, and that countries experiencing rapid 
technological progress should exhibit a rising real exchange rate in terms of price indexes that include nontradables, such as the CPI. A direct test of the BalassaSamuelson hypothesis would require data on productivity over time, which are difficult to obtain for many countries. As a proxy, this paper uses real per capita GNP. Chinn and Johnston (1996) and Mark and Choi (1995) find evidence for a positive correlation between productivity or per capita income and the CPI real exchange rate using a subset of the countries examined in this paper.

A partial test of the Balassa-Samuelson hypothesis is to examine the impact of the CPI-WPI ratio on the CPI real exchange rate to confirm whether movements in the tradables-nontradables price ratio plays a significant role in real exchange rate movements. Rogoff (1996) shows that the WPI real exchange rate between Japan and the United States has exhibited a much smaller drift over time than the CPI real exchange rate.

Froot and Rogoff (1991) and DeGregorio, Giovannini, and Wolf (1994) find evidence of a temporary effect of government spending on the CPI real exchange rate. They argue that higher government spending tends to appreciate the real exchange rate because it falls more heavily on nontraded goods. Rogoff (1992) argues that the long-run effects of government spending are much smaller than the short-run effects. Nevertheless, Chinn and Johnston (1996) claim that the ratio of real government consumption to real GDP does have a long-run effect on the real CPI exchange rate. 
The Data

The dataset is an annual panel with observations for 20 industrial countries from 1960 through $1995 .^{3}$ The basic regressions were run over the floating-rate period beginning in 1973. The series were obtained from the International Financial Statistics database maintained by the International Monetary Fund. ${ }^{4}$ For the basic regressions, all exchange rates were defined vis-a-vis Germany, and the German data were dropped from the regressions. ${ }^{5}$ The data mnemonics and definitions are presented in Table 1. Net foreign assets are scaled by trade flows because equilibrium is achieved through the operation of the real exchange rate on the trade sector of the economy.

\section{Univariate Analysis}

Figures 1-6 plot the data starting in 1970. Most of the real exchange rate series exhibit large swings around a slowly drifting or constant mean. For the WPI real exchange rate, the primary exceptions are those of Germany's immediate neighbors--

\footnotetext{
${ }^{3}$ Australia, Austria, Belgium, Canada, Denmark, Finland, France, Germany, Greece, Ireland, Italy, Japan, the Netherlands, New Zealand, Norway, Spain, Sweden, Switzerland, the United Kingdom, and the United States. Due to missing observations for certain series the sample begins in 1980 for Germany, and it ends in 1992 for Finland and 1994 for Belgium, Germany, Italy, and Greece.

${ }^{4}$ Finnish net factor income was obtained from OECD Annual National Accounts. Belgian and French wholesale prices were obtained from national sources.

${ }^{5}$ Frenkel (1981) was the first to note that the evidence for purchasing power parity is weaker when using dollar exchange rates, a finding confirmed by Edison, Gagnon, and Melick (forthcoming). As discussed below, use of the United States as the partner country has only a small effect on the results of this paper.
} 


\begin{tabular}{||l|l||}
\hline \multicolumn{2}{||c||}{ Table 1 Data Definitions } \\
\hline REC & Log real exchange rate using CPIs (increase = appreciation) \\
\hline REW & Log real exchange rate using WPIs (increase = appreciation) \\
\hline NFA & $\begin{array}{l}\text { Net foreign assets (calculated by cumulating exports plus net } \\
\text { factor income minus imports since 1960) divided by exports } \\
\text { plus imports of goods and services }\end{array}$ \\
\hline CWR & Log ratio of CPI to WPI \\
\hline YPC & Log real GNP per capita \\
\hline GOV & Ratio of government consumption to nominal GDP \\
\hline
\end{tabular}

Austria, Denmark, the Netherlands, and Switzerland--which are characterized by much smaller movements and very little drift. A downward drift is noticeable for Australia, Canada, and the United States. An upward drift is apparent for Japan.

NFA drifts upward in Japan and Switzerland, and downward in Australia, New Zealand, and the United States, with little trend in the remaining countries. CWR drifts upward in most countries. YPC exhibits a pronounced upward trend in every country. Finally, GOV has either a small upward trend or no trend in every country.

Table 2 presents the results of panel unit root tests for each variable. The tests were conducted by regressing the first difference of the variable on its lagged level, lagged first differences of the variable, and a full set of country and year dummy variables, as shown in equation (1). Four lagged differences were included in the initial regressions and the lag length was truncated sequentially by dropping 
coefficients that were not significant at the 10 percent level. ${ }^{6}$ In most cases only one lagged difference was retained, but in all cases the adjustment coefficient was completely insensitive to the choice of lag length and the test statistic was only moderately affected.

$$
\begin{aligned}
& \Delta R E x_{i t}=\rho R E x_{i t-1}+\sum_{k=1}^{4} \beta_{k} \Delta R E x_{i t-k}+\alpha_{i}+\tau_{t} \\
& i=19 \text { industrial countries } \quad t=1973, \ldots, 1995
\end{aligned}
$$

Levin and Lin (1992) show that estimation of country-specific intercepts biases if adjustment coefficient, $\rho$, and the associated test statistic downward. They $p_{i} v: d:$ a tatle of adjusted critical values from Monte Carlo simulations of different sarnple sizes which is the basis for the significance levels in Table 2. O'Connell (1996) points out that the definition of all exchange rates in terms of a common country can lead to a cross-country correlation in the residual that also tends to bias the test stat'stic downward. By estimating a complete set of time effects, the regression is a le tc sontrol fcr the common influence of the omitted country, Germany.

Both real exchange rates appear to be stationary. ${ }^{7}$ The real exchange rate using WPIs exhibits stronger mean reversion than that using CPIs, which may reflect the greater tradability of the components of the WPI. There is weak evidence of mean reversion of the CPI-WPI ratio and the government consumption ratio. There is no

${ }^{6} \mathrm{I}$ also tested for the significance of a full set of country-specific dynamic coefficients. I found them to be significant only for YPC and GOV, and their inclusion had no material effect on the unit root test statistics for YPC and GOV.

${ }^{7}$ Using exchange rates vis-a-vis the United States leads to nearly identical results. 
evidence of mean reversion in net

foreign assets and real per capita

incomes.

Further evidence on the time-

series properties of these data can be

derived by analyzing the estimated time

effects from the panel data regressions.

These time effects capture the

movements common to all countries

over time, and they may themselves

\begin{tabular}{|c|c|c|}
\hline \multicolumn{3}{|c|}{$\begin{array}{l}\text { Table } 2 \text { Panel Unit Root Tests } \\
\text { (Equation (1)) }\end{array}$} \\
\hline Variable & $\begin{array}{l}\text { Adjustment } \\
\text { Coefficient }\end{array}$ & $\begin{array}{c}\text { Test } \\
\text { Statistic }\end{array}$ \\
\hline REC & -.25 & $-8.0^{* * *}$ \\
\hline REW & -.32 & $-8.8^{* * *}$ \\
\hline NFA & -.01 & -1.3 \\
\hline CWR & -.14 & $-6.6^{*}$ \\
\hline YPC & -.08 & -4.0 \\
\hline GOV & -.19 & -6.4 \\
\hline
\end{tabular}

contain unit roots. To perform the

analysis, I combined the time-effect coefficients sequentially to create a new data

vector for each variable listed in Table 2. I then conducted augmented Dickey-Fuller

tests with one lagged difference on these data vectors. The tests revealed that the estimated time effects are stationary at the 5 percent level for all variables except YPC.

\section{Multivariate Analysis}

In light of the evidence of the previous section that real exchange rates are stationary, it may seem unlikely that there exist significant correlations between real exchange rates and the remaining variables in the dataset, which appear to be nonstationary, or, at most, borderline stationary. However, it is important to 
recognize that the maintained assumption of the panel unit root test is that either all series are stationary or all series have unit roots. Recall that the plots of the data revealed that real exchange rates exhibit drifts in certain countries, but not in other countries. The pattern of drifts over time also varied across countries for the other variables, raising the possibility that some of the other variables may be able to explain the apparent long-run movements of the real exchange rates of certain countries.

The approach taken here is purely empirical. The goal is to search for a longrun correlation between the real exchange rate and any or all of the explanatory variables. No attempt is made to identify a theoretical structural relationship. However, significant evidence of a long-run correlation, or cointegrating vector, may be taken as evidence on the types of shocks and transmission channels that are important in the data.

In a truly long sample, one could simply regress the real exchange rate on the explanatory variables. However, in the relatively short sample available, dynamic adjustments to shocks, and feedback from the exchange rate to some of the explanatory variables, may lead to biased estimates of the long-run correlations. Moreover, the adjustment dynamics and feedback effects may be of interest in themselves. Phillips and Loretan (1991) provide a methodology for dealing with these issues in short samples.

As shown in equation (2), the regressions of the previous section are augmented to include the other four variables. The term in parentheses is the long- 
run cointegrating relationship between the real exchange rate and the explanatory variables. The error-correction coefficient, $\rho$, captures the long-run adjustment speed to deviations from equilibrium. In order to control for short-run dynamics and feedback effects from the real exchange rates to the independent variables, I included backward and forward differences of the independent variables as well as lagged differences of the real exchange rate. Additional lags of the explanatory variables were not significant, presumably reflecting the fact that exchange rates respond quickly to economic news. Finally, the regressions include a full set of country and time effects.

$$
\begin{aligned}
\Delta R E x_{i t} & =\rho\left(R E x_{i t-1}-\gamma_{1} N F A_{i t-1}-\delta_{1} C W R_{i t-1}-\theta_{1} Y P C_{i t-1}-\lambda_{1} G O V_{i t-1}\right) \\
+ & \gamma_{2} \Delta N F A_{i t+1}+\gamma_{3} \Delta N F A_{i t}+\delta_{2} \Delta C W R_{i t+1}+\delta_{3} \Delta C W R_{i t} \\
& +\theta_{2} \Delta Y P C_{i t+1}+\theta_{3} \Delta Y P C_{i t}+\lambda_{2} \Delta G O V_{i t+1}+\lambda_{3} \Delta G O V_{i t} \\
& +\sum_{k=1}^{4} \beta_{k} \Delta R E x_{i t-k}+\alpha_{i}+\tau_{t} \\
& i=19 \text { industrial countries } \quad t=1973, \ldots, 1994
\end{aligned}
$$

In order to obtain a parsimonious and robust specification, I performed sequential tests on the estimates of equation (2). First, I tested the lagged differences of the real exchange rates. The second, third, and fourth lags were never individually or jointly significant at the 10 percent level, so they were dropped from the regression. Next I tested the significance of the independent variables. ${ }^{8}$ For each variable I tested the joint significance of the lagged level, forward difference, and backward difference. YPC was never significant at the 10 percent level. GOV was

${ }^{8}$ According to Levin and Lin (1992), if one accepts the hypothesis of cointegration (based on the estimated error-correction coefficient, $\rho$, and its standard error) the coefficients on the levels of the explanatory variables have standard distributions. 
significant at the 5 percent level for REC and the 10 percent level for REW. NFA and CWR were always significant at the 1 percent level. After dropping YPC from the regressions, further tests revealed that only the forward difference of GOV was significant. The lagged level and backward difference of GOV were dropped. The results are presented in Table 3.

According to the first column of Table 3, a future increase in government spending of 1 percent of GDP causes an immediate increase in the real exchange rate of $u .87$ percent. While it is possible that this correlation arises because shocks to the exchange rate affect future government spending, a more plausible interpretation is that the political process makes fiscal policy highly forecastable. Thus, forwardlooking exchange markets can price in the effect of future government spending. As discussed above, government spending has no significant long-run effect on either REC or REW.

Changes in the CPI-WPI ratio show up one-for-one in the CPI real exchange rate (REC) immediately (from the coefficient on $\Delta C W R_{i t}$ ), but in the long run only about two-thirds of these changes are reflected in the CPI real exchange rate (from the coefficient on $\left(W R_{\mathrm{it}-1}\right)$. These estimates are consistent with those from the REW equation: changes in the CPI-WPI ratio have no immediate effect on the WPI real exchange rate, but they tend to reduce the WPI real exchange rate in the long run. If international arbitrage equates the prices of the components of WPIs and not the components of CPIs, one would expect to observe a long-run coefficient on CWR of 1 in the REC equation and 0 in the REW equation. On the other hand, if CPIs are 
arbitraged and WPIs are not, one would expect to observe a coefficient on CWR of 0 in the REC equation and -1 in the REW equation. These estimates imply that arbitrage works better for the components of WPIs, but that a weighted average of WPIs and CPIs is more stable than either index alone.

The positive coefficient on future changes in the CPI-WPI ratio reflects the feedback of the exchange rate onto domestic prices. Exchange rate appreciations tend to reduce WPIs more than CPIs, thereby increasing CWR in the following period.

Turning to the effect of NFA, Table 3 displays a significant positive correlation between the real exchange

\begin{tabular}{|c|c|c|}
\hline \multicolumn{3}{|c|}{$\begin{array}{c}\text { Table } 3 \text { Multivariate Results } \\
\text { (Equation (2)) }\end{array}$} \\
\hline & $\Delta R C_{i t}$ & $\triangle$ REW $_{\text {it }}$ \\
\hline E.C. $(\rho)$ & $\begin{array}{l}-.34^{* * *} \\
(.04)\end{array}$ & $\begin{array}{l}-.34^{* * *} \\
(.04)\end{array}$ \\
\hline $\mathrm{NFA}_{\mathrm{it}-1}$ & $\begin{array}{l}.11^{* * *} \\
(.03)\end{array}$ & $\begin{array}{l}.10^{* * *} \\
(.03)\end{array}$ \\
\hline$C W R_{i t-1}$ & $\begin{array}{l}.66^{* * *} \\
(.16)\end{array}$ & $\begin{array}{l}-.26^{*} \\
(.16)\end{array}$ \\
\hline$\Delta \mathrm{NFA}_{\mathrm{it}+1}$ & $\begin{array}{l}-.15^{* * *} \\
(.05)\end{array}$ & $\begin{array}{l}-.14^{* * *} \\
(.05)\end{array}$ \\
\hline$\Delta \mathrm{NFA}_{\mathrm{it}}$ & $\begin{array}{l}.24^{* * *} \\
(.05)\end{array}$ & $\begin{array}{l}.24^{* * *} \\
(.05)\end{array}$ \\
\hline$\Delta C W R_{i t+1}$ & $\begin{array}{l}.34^{* * *} \\
(.11)\end{array}$ & $\begin{array}{l}.33^{* * *} \\
(.11)\end{array}$ \\
\hline$\Delta C W R_{i t}$ & $\begin{array}{l}1.14^{* * *} \\
(.11)\end{array}$ & $\begin{array}{l}.16 \\
(.10)\end{array}$ \\
\hline$\Delta \mathrm{GOV}_{\mathrm{it}+1}$ & $\begin{array}{l}.87^{* *} \\
(.35)\end{array}$ & $\begin{array}{l}.84^{* *} \\
(.35)\end{array}$ \\
\hline$\Delta \mathrm{REx}_{\mathrm{it}-1}$ & $\begin{array}{l}.13^{* * *} \\
(.04)\end{array}$ & $\begin{array}{l}.19^{* * *} \\
(.05)\end{array}$ \\
\hline $\mathbf{R}^{2}$ & .66 & .59 \\
\hline std. error & .046 & .045 \\
\hline No. Obs. & 414 & 414 \\
\hline \multicolumn{3}{|c|}{$\begin{array}{l}* * *, * * \text { and } * \text { denote significance at the } 1 \text {, } \\
5 \text {, and } 10 \text { percent levels, respectively. }\end{array}$} \\
\hline
\end{tabular}
rate and the level of net foreign assets.

When net foreign assets increase by an amount equal to total exports plus imports $(\triangle N F A=1)$ the real exchange rate appreciates by 24 percent in the short run and $10-11$ percent in the long run. The short-run effect is much larger because the exchange 
rate is a forward-looking variable and current account balances are very persistent. Thus, a small increase in the growth rate of NFA tends to lead to a large permanent increase in the level of NFA. The negative coefficient on future changes in NFA reflects the equilibrating nature of the system, as an appreciating exchange rate puts downward pressure on the future growth rate of NFA. To put these estimates in perspective, the United States' current account balance in 1994 was equal to about 10 percent of exports plus imports of goods and services. A permanent decrease in NFA of this magnitude would be expected to depreciate the real exchange rate by 1 percent in the long run.

As in the previous section, an augmented Dickey-Fuller test strongly rejects the hypothesis of a unit root in the estimated time effects of both regressions presented in Table 3. Figure 7 plots the time effects from the REW regression. The horizontal line represents the mean value of the estimated time effects. ${ }^{9}$

\section{Robustness}

Table 4 compares the basic results for the WPI real exchange rate with five alternative specifications to provide evidence on the robustness of the estimated relationship between net foreign assets and the real exchange rate. The first column reprints the estimates from the last column of Table 2. The short-run dynamic coefficients on CWR and GOV are omitted. The second column presents estimates of

\footnotetext{
${ }^{9}$ The inclusion of a full set of country dummies necessitates a zero restriction on one of the time effects, in this case the 1994 dummy was dropped.
} 


\begin{tabular}{|c|c|c|c|c|c|c|}
\hline & $\begin{array}{l}\text { Basic } \\
\text { Model }\end{array}$ & $\begin{array}{c}\text { Basic } \\
\text { Model } \\
1962-94\end{array}$ & $\begin{array}{l}\text { NFI proxy } \\
\text { for NFA }\end{array}$ & $\begin{array}{l}\text { Country- } \\
\text { Specific } \\
\text { Trends }\end{array}$ & $\begin{array}{l}\text { Country- } \\
\text { Specific } \\
\text { Dynamics }\end{array}$ & $\begin{array}{l}\text { U.S. as } \\
\text { Reference } \\
\text { Country }\end{array}$ \\
\hline E.C. $(\rho)$ & $\begin{array}{l}-.34^{* * *} \\
(.04)\end{array}$ & $\begin{array}{l}-.23^{* * *} \\
(.03)\end{array}$ & $\begin{array}{l}-.35^{* * *} \\
(.04)\end{array}$ & $\begin{array}{l}-.54^{* * *} \\
(.05)\end{array}$ & $\begin{array}{l}-.40^{* * *} \\
(.04)\end{array}$ & $\begin{array}{l}-.35^{* * *} \\
(.04)\end{array}$ \\
\hline $\mathrm{NFA}_{\mathrm{it}-1}$ & $\begin{array}{l}.10^{* *} \\
(.03)\end{array}$ & $\begin{array}{l}.14^{* * *} \\
(.04)\end{array}$ & $\begin{array}{l}1.22^{* * *} \\
(.45)\end{array}$ & $\begin{array}{l}.11^{* *} \\
(.05)\end{array}$ & $\begin{array}{l}.09^{* * *} \\
(.03)\end{array}$ & $\begin{array}{l}.08^{* *} \\
(.03)\end{array}$ \\
\hline$C W R_{i t-1}$ & $\begin{array}{l}-.26^{*} \\
(.16)\end{array}$ & $\begin{array}{l}-.17 \\
(.11)\end{array}$ & $\begin{array}{l}-.16 \\
(.16)\end{array}$ & $\begin{array}{l}.25 \\
(.17)\end{array}$ & $\begin{array}{l}-.23 \\
(.14)\end{array}$ & $\begin{array}{l}-.27^{*} \\
(.15)\end{array}$ \\
\hline$\Delta \mathrm{NFA}_{\mathrm{it}+1}$ & $\begin{array}{l}-.14^{* * *} \\
(.05) \\
\end{array}$ & $\begin{array}{l}-.12^{* * *} \\
(.04)\end{array}$ & $\begin{array}{c}.11 \\
(.31)\end{array}$ & $\begin{array}{l}-.15^{* * *} \\
(.06)\end{array}$ & n.a. & $\begin{array}{l}-.15^{* * *} \\
(.05)\end{array}$ \\
\hline$\Delta \mathrm{NFA}_{\mathrm{it}}$ & $\begin{array}{l}.24^{* * *} \\
(.05)\end{array}$ & $\begin{array}{l}.19^{* * *} \\
(.04)\end{array}$ & $\begin{array}{l}-.35 \\
(.32)\end{array}$ & $\begin{array}{l}.17^{* *} \\
(.05)\end{array}$ & n.a. & $\begin{array}{l}.25^{* * *} \\
(.05)\end{array}$ \\
\hline$\Delta \mathrm{REW}_{\mathrm{it}-1}$ & $\begin{array}{l}.19^{* * *} \\
(.05)\end{array}$ & $\begin{array}{l}.18^{* * *} \\
(.04)\end{array}$ & $\begin{array}{l}.20^{* * *} \\
(.05)\end{array}$ & $\begin{array}{l}.25^{* * *} \\
(.05)\end{array}$ & n.a. & $\begin{array}{l}.18^{* * *} \\
(.05)\end{array}$ \\
\hline $\mathrm{R}^{2}$ & .59 & .50 & .57 & .65 & .69 & .80 \\
\hline No. Obs. & 414 & 593 & 411 & 414 & 414 & 406 \\
\hline
\end{tabular}

the basic specification over the entire sample from 1962 through 1993. Not surprisingly--given the switch from fixed to floating exchange rates--there is evidence of a structural break in the adjustment speed coefficient, but one can still reject noncointegration at the 1 percent level. (It is because of this structural break that most of the regressions focus on the floating-rate period only.) Using the entire sample, the long-run estimated effect of NFA on REW is even greater and more significant than in the floating rate subsample. 
The second alternative examines the effect of measurement error in net foreign assets. NFA is calculated by cumulating the own-currency current account balances over time. ${ }^{10}$ The lack of an initial benchmark value has no effect on the estimated coefficient since there is a complete set of country-specific intercepts in the regression. However, the calculation of NFA ignores valuation effects on the gross stocks of foreign assets and liabilities due to movements in exchange rates, equity prices, and land prices. In addition, there are large errors and omissions in the international current accounts data. The third column presents estimates using the ratio of net factor income to total trade (NFI) as an alternative measure of NFA. In theory, NFI should be equal to a market rate of return times the level of NFA. If the rate of return were around 5 to 10 percent, one would expect the coefficient on NFI to be around 10 to 20 times larger than that on NFA. As shown in Table 4, the estimated coefficient on NFI is 12 times larger than that on NFA, implying an average rate of return of 8 percent. The short-run impact of changes in NFI appear quite different from those of NFA. This difference probably reflects the tendency for foreign assets to be denominated in foreign currencies and foreign liabilities to be denominated in domestic currency. Periods of exchange-rate appreciation are thus associated with declining net factor income, as the domestic-currency value of earnings on foreign assets declines relative to payments on foreign liabilities.

${ }^{10} \mathrm{As}$ the sum of net factor income and exports minus imports of goods and services, NFA differs from a cumulated current account balance slightly due to the omission of unilateral transfers. 
The next two alternatives consider different econometric specifications. The fourth column displays the effect of including country-specific time trends in the regression. The specification with time trends yields a somewhat faster estimated adjustment speed and a positive, but insignificant, long-run effect of CWR on REW. The estimated long-run effect of NFA is essentially unaffected. The fifth column displays the effect of estimating separate coefficients for each country on the lagged difference of the exchange rate and the forward and backward differences of net foreign assets. Despite the profligate parameterization of this specification, the coefficient on the level of NFA is nearly identical to its value in the basic specification.

Finally, the last column presents the estimates of the basic specification when all exchange rates are defined relative to the United States. In this regression the U.S. data are dropped and the German data are included. The results are very similar to those of the first column.

\section{Interpretation of Results}

The statistical results of the previous three sections suggest a paradox: Real exchange rates are stationary; net foreign assets are nonstationary; yet there is a longrun correlation between real exchange rates and net foreign assets. The solution to this paradox is apparent in Figure 8 .

The solid lines are log WPI real exchange rates (REW), demeaned by country. The cross symbols represent the long-run effect of the ratio of net foreign assets to 
total trade (NFA) and the CPI-WPI ratio (CWR) on REW from the basic regression, also demeaned by country. The cross symbols are estimates of the long-run equilibrium real exchange rate. In every country, the variance of the real exchange rate exceeds the variance of the equilibrium exchange rate. In many countries, the equilibrium real exchange rate is essentially a constant, reflecting the stability of NFA and the very small effect of CWR. For these countries, the real exchange rate is stationary. Since these countries dominate the sample, the panel unit root test is able to reject the hypothesis that all real exchange rates contain a unit root.

However, for several countries--notably Australia, Japan, New Zealand, Switzerland, and the United States--NFA does have a visible trend. These countries provide the evidence in favor of a long-run effect of NFA on REW. ${ }^{11}$ To take two important examples: Between 1973 and 1994 NFA fell from .53 to -.45 in the United States, implying a permanent real exchange rate depreciation of nearly 10 percent. During the same period in Japan, NFA rose from .29 to 2.0 , implying a permanent real appreciation of roughly 17 percent. Thus, movements in net foreign assets can explain a cumulative drift of 27 percent in the U.S.-Japanese real exchange rate over the past 20 years, which is nearly two-thirds of the total movement in the real bilateral exchange rate over this period.

${ }^{11}$ When these countries are excluded from the regression, the long-run coefficient on NFA is greatly reduced but the new estimate is only about one standard deviation lower than the original estimate. The remaining coefficients are affected only slightly. 
References

Alesina, Alberto and Roberto Perotti (1995) "Taxation and Redistribution in an Open Economy," European Economic Review 39, 961-79.

Balassa, Bela (1964) "The Purchasing Power Parity Doctrine: A Reappraisal," Journal of Political Economy 72, 584-96.

Chinn, Menzie, and Louis Johnston (1996) "Real Exchange Rate Levels, Productivity and Demand Shocks: Evidence from a Panel of 14 Countries," NBER Working Paper No. 5709, August.

De Gregorio, Jose, Alberto Giovannini, and Holger Wolf (1994) "International Evidence on Tradables and Nontradables Inflation," European Economic Review $38,1225-44$.

Dornbusch, Rudiger, and Stanley Fischer (1980) "Exchange Rates and the Current Account," American Economic Review 70, 960-71.

Edison, Hali J., Joseph E. Gagnon, and William R. Melick (forthcoming) "Understanding the Empirical Literature on Purchasing Power Parity: The Bretton Woods Era," Journal of International Money and Finance.

Faruqee, Hamid (1995) "Long-Run Determinants of the Real Exchange Rate: A StockFlow Perspective," IMF Staff Papers 42, 80-107.

Frankel, Jeffrey A., and Andrew K. Rose (1996) "Mean Reversion Within and Between Countries: A Panel Study of Purchasing Power Parity," Journal of International Economics 40, 209-24.

Frenkel, Jacob A. (1981) "Flexible Exchange Rates, Prices, and the Role of News: Lessons from the 1970s," Journal of Political Economy 89, 665-705.

Froot, Kenneth A., and Kenneth Rogoff (1991) "The EMS, the EMU, and the Transition to a Common Currency," in Blanchard and Fischer, eds., NBER Macroeconomics Annual 1991 (Cambridge: The MIT Press). (1995) "Perspectives on PPP and Long-Run Real Exchange Rates," in Grossman and Rogoff, eds., Handbook of International Economics (Amsterdam: North Holland Press).

Gavin, Michael (1991) "Terms of Trade, The Trade Balance, and Stability: The Role of Savings Behavior," International Finance Discussion Papers No. 397, Board of Governors of the Federal Reserve System. 
Hooper, Peter and John Morton (1982) "Fluctuations in the Dollar: A Model of Nominal and Real Exchange Rate Determination," Journal of International Money and Finance 1, 39-56.

Levin, Andrew, and Chien-Fu Lin (1992) "Unit Root Tests in Panel Data: Asymptotic and Finite-Sample Properties," University of California at San Diego Discussion Paper 92-23.

Mark, Nelson and Doo-Yull Choi (1995) "Real Exchange-Rate Prediction over Long Horizons," Ohio State University manuscript, November.

Marquez, Jaime (1990) "Bilateral Trade Elasticities," Review of Economics and Statistics $72,70-77$.

Obstfeld, Maurice (1982) "Aggregate Spending and the Terms of Trade: Is There a Laursen-Metzler Effect?" Quarterly Journal of Economics 97, 251-70.

Obstfeld, Maurice and Kenneth Rogoff (1995) "The Intertemporal Approach to the Current Account," in Grossman and Rogoff, eds., Handbook of International Economics (Amsterdam: North Holland Press).

O'Connell, Paul G. (1996) "The Overvaluation of Purchasing Power Parity," Harvard University manuscript, January.

Papell, David H. (forthcoming) "Searching for Stationarity: Purchasing Power Parity under the Current Float," Journal of International Economics.

Phillips, Peter and Mico Loretan (1991) "Estimating Long-Run Economic Equilibria," Review of Economic Studies 58, 407-36.

Rogoff, Kenneth (1996) "The Purchasing Power Parity Puzzle," Journal of Economic Literature 34, 647-68.

Samuelson, Paul A. (1964) "Theoretical Notes on Trade Problems," Review of Economics and Statistics $46,145-54$.

Wei, Shang-Jin and David Parsley (1995) "Purchasing Power Disparity during the Floating Rate Period: Exchange Rate Volatility, Trade Barriers, and Other Culprits," NBER Working Paper No. 5032, February. 

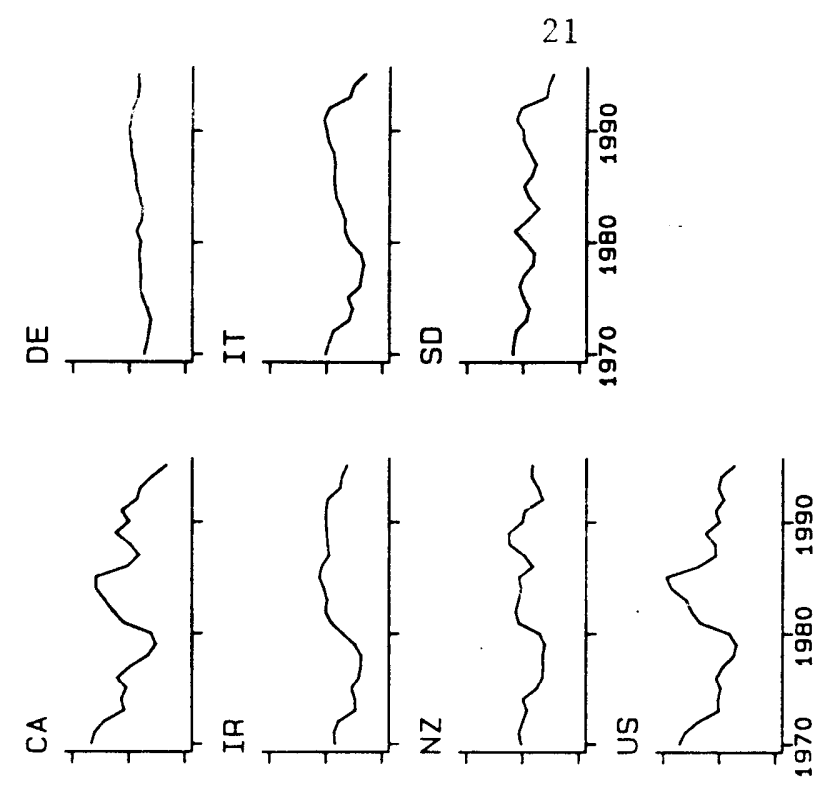

0
0
0
0

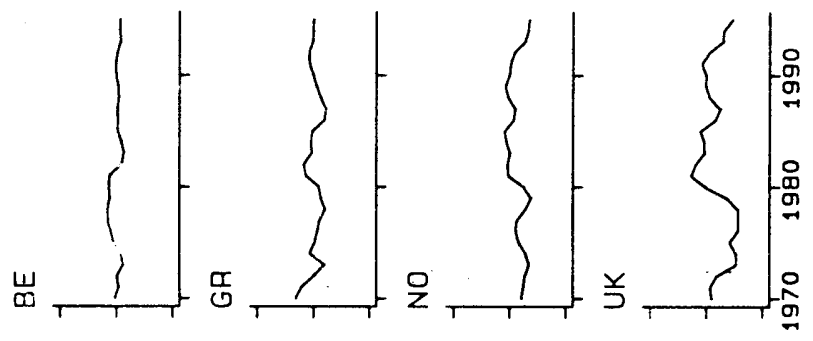

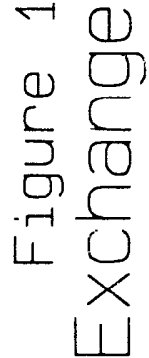
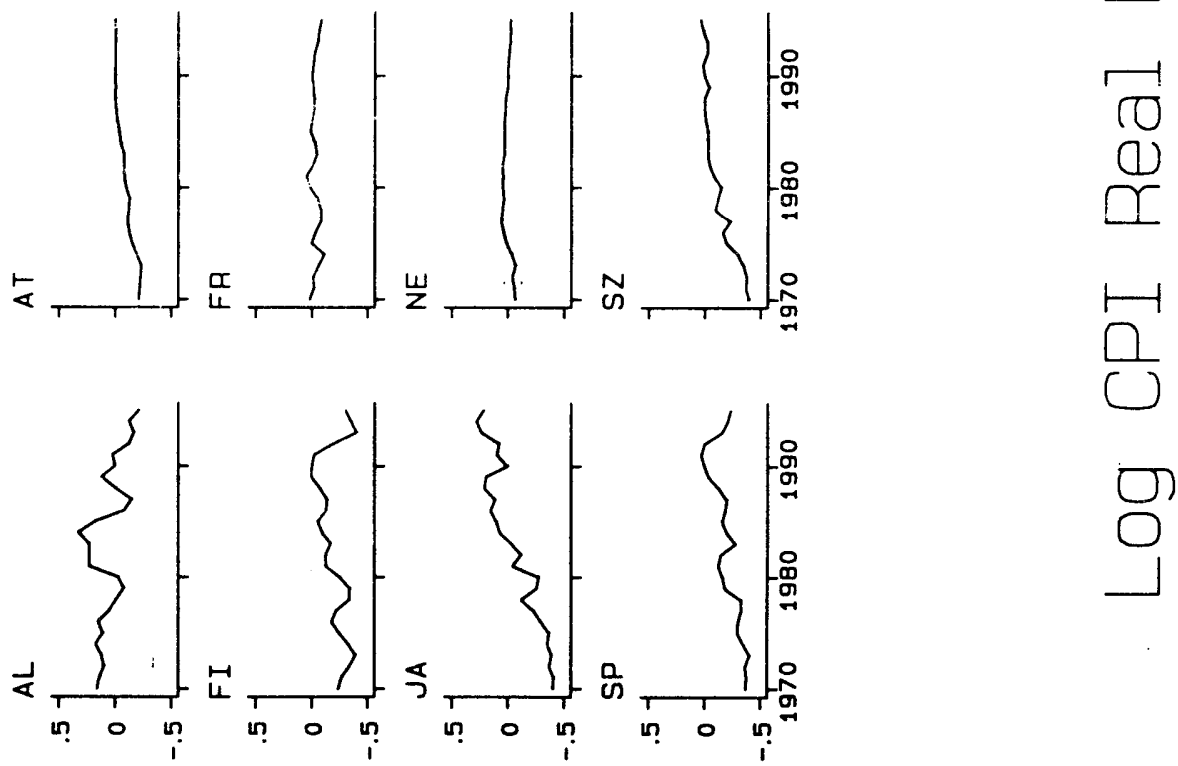

$\frac{0}{10}$

$\underset{\square}{\square}$ 

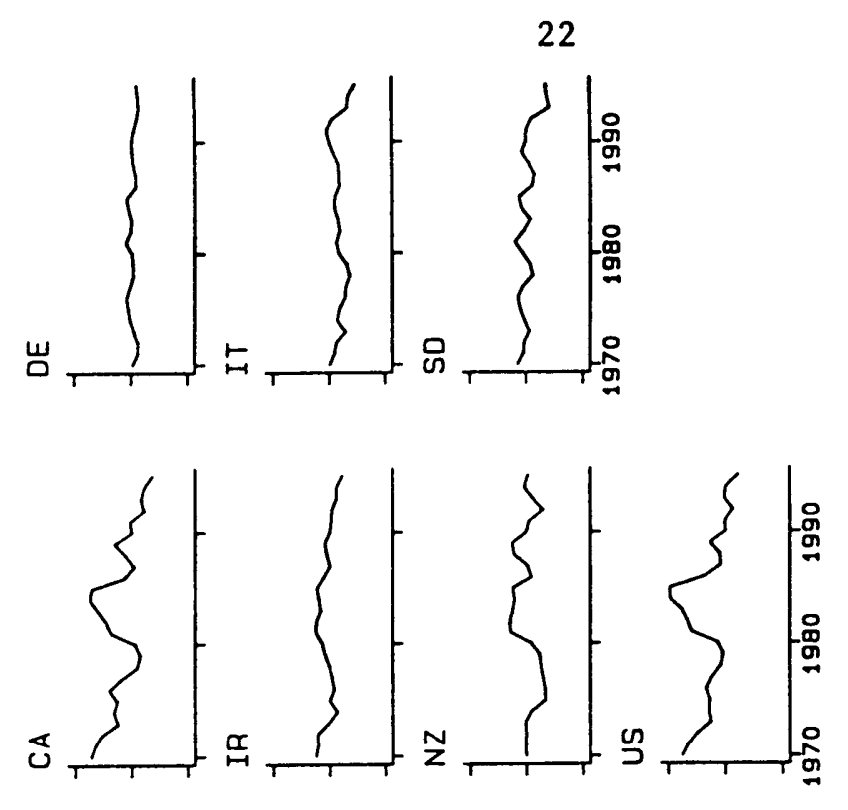

0
0
0

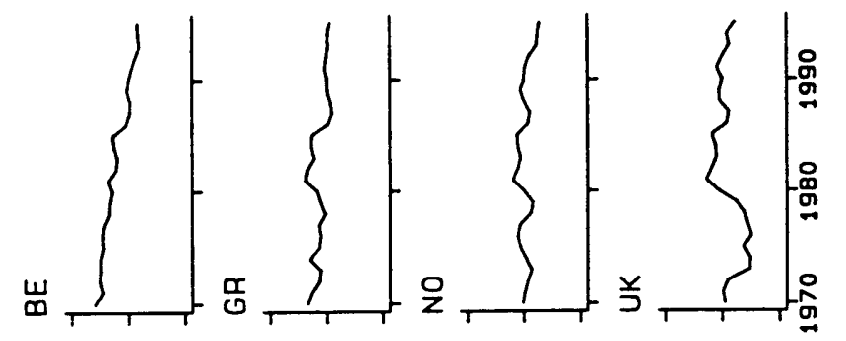

$\frac{0}{10}$

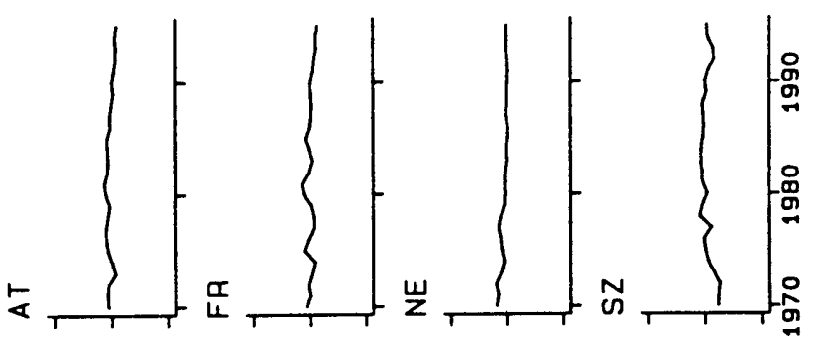

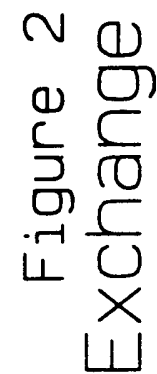

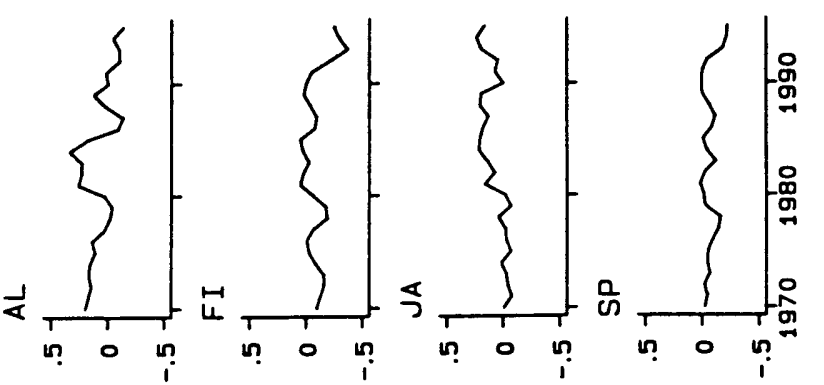

01
0
$\frac{1}{12}$
$\frac{1}{3}$

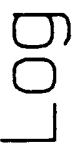



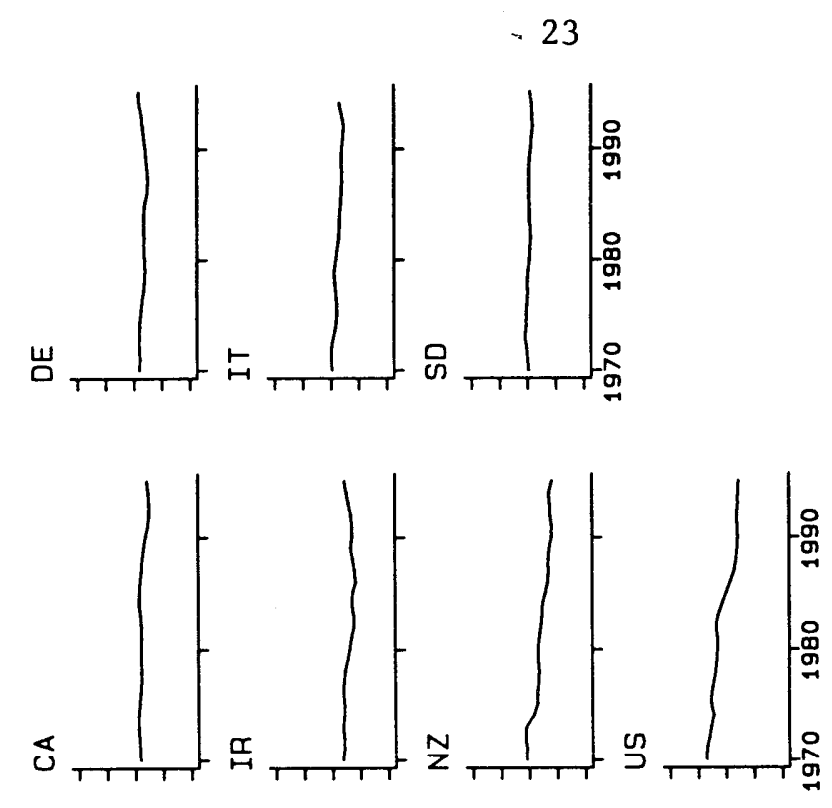

$\frac{0}{0}$

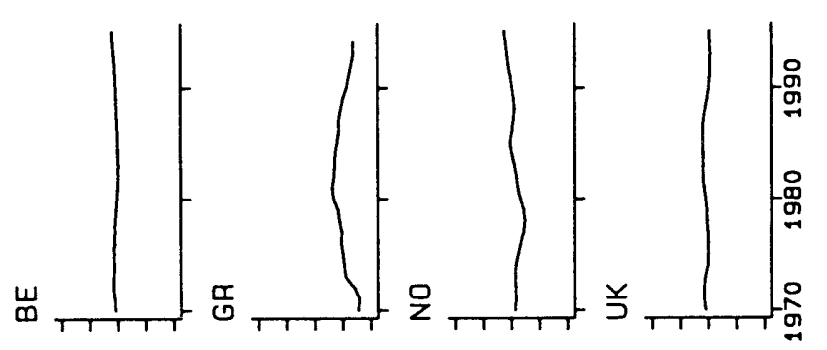

$m+$

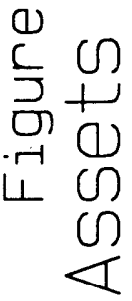
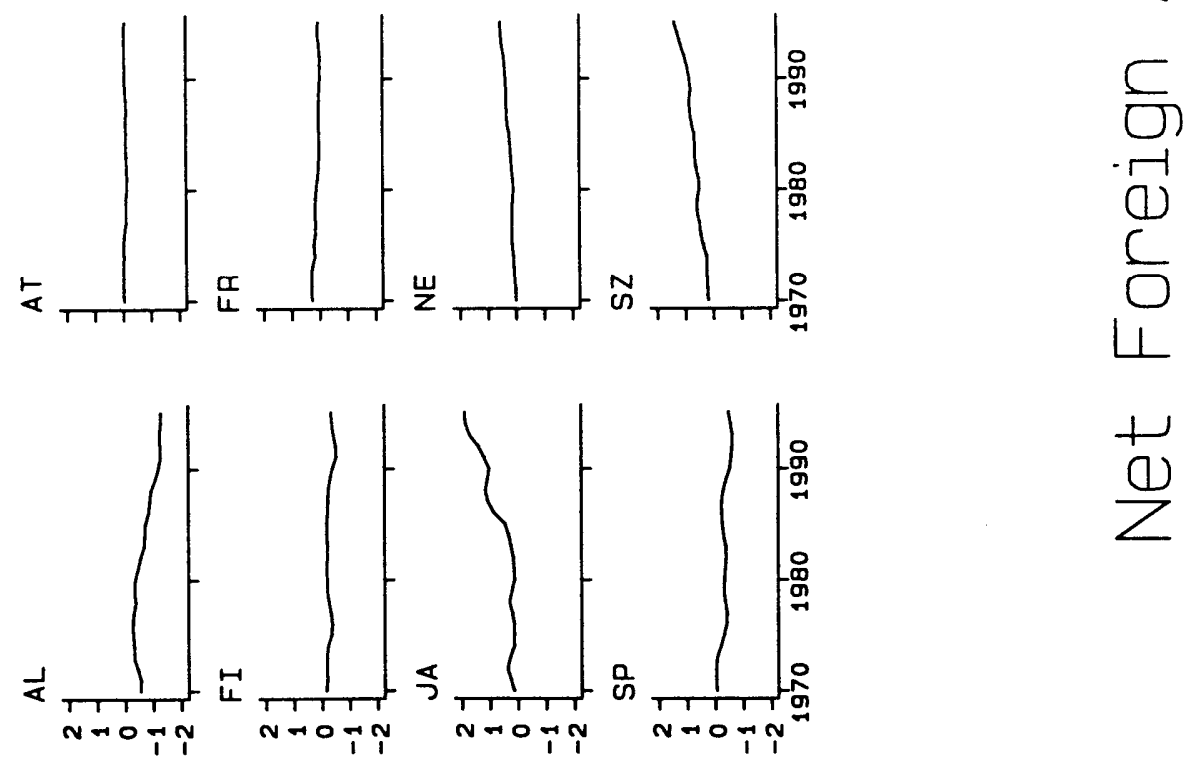

$\frac{1}{2}$ 

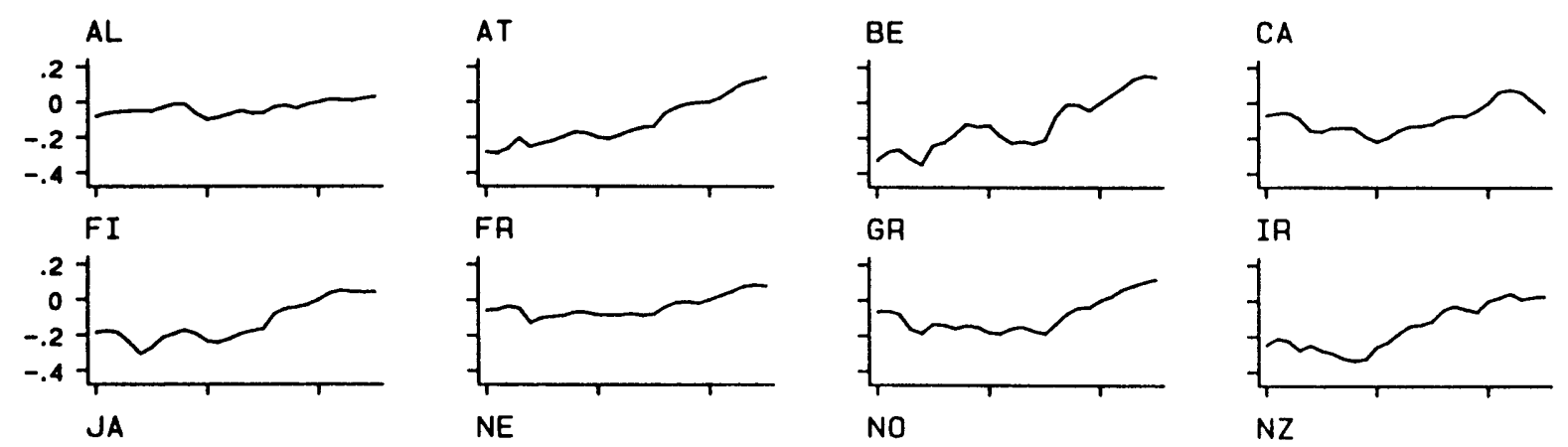

DE
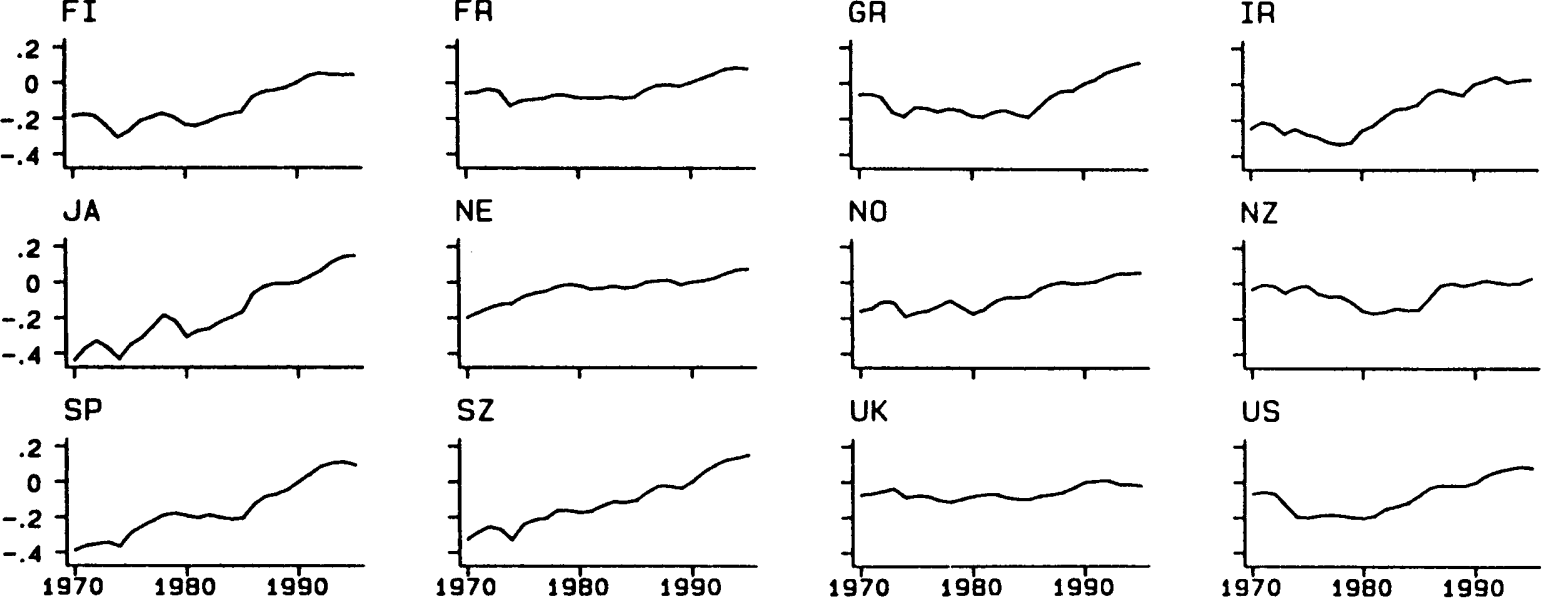

US
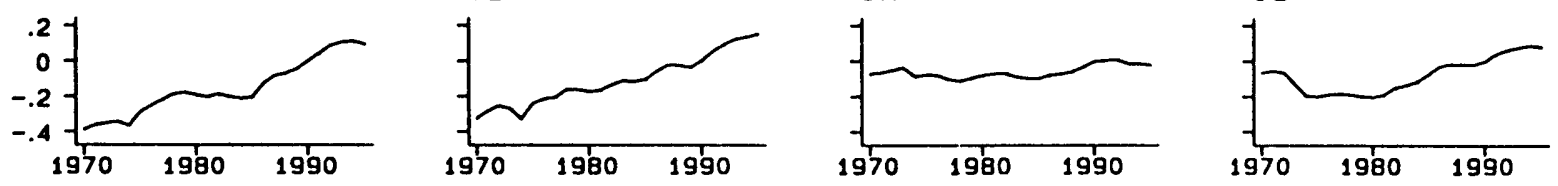

Figure 4

Log CPI-WPI Ratio (1990=0) 

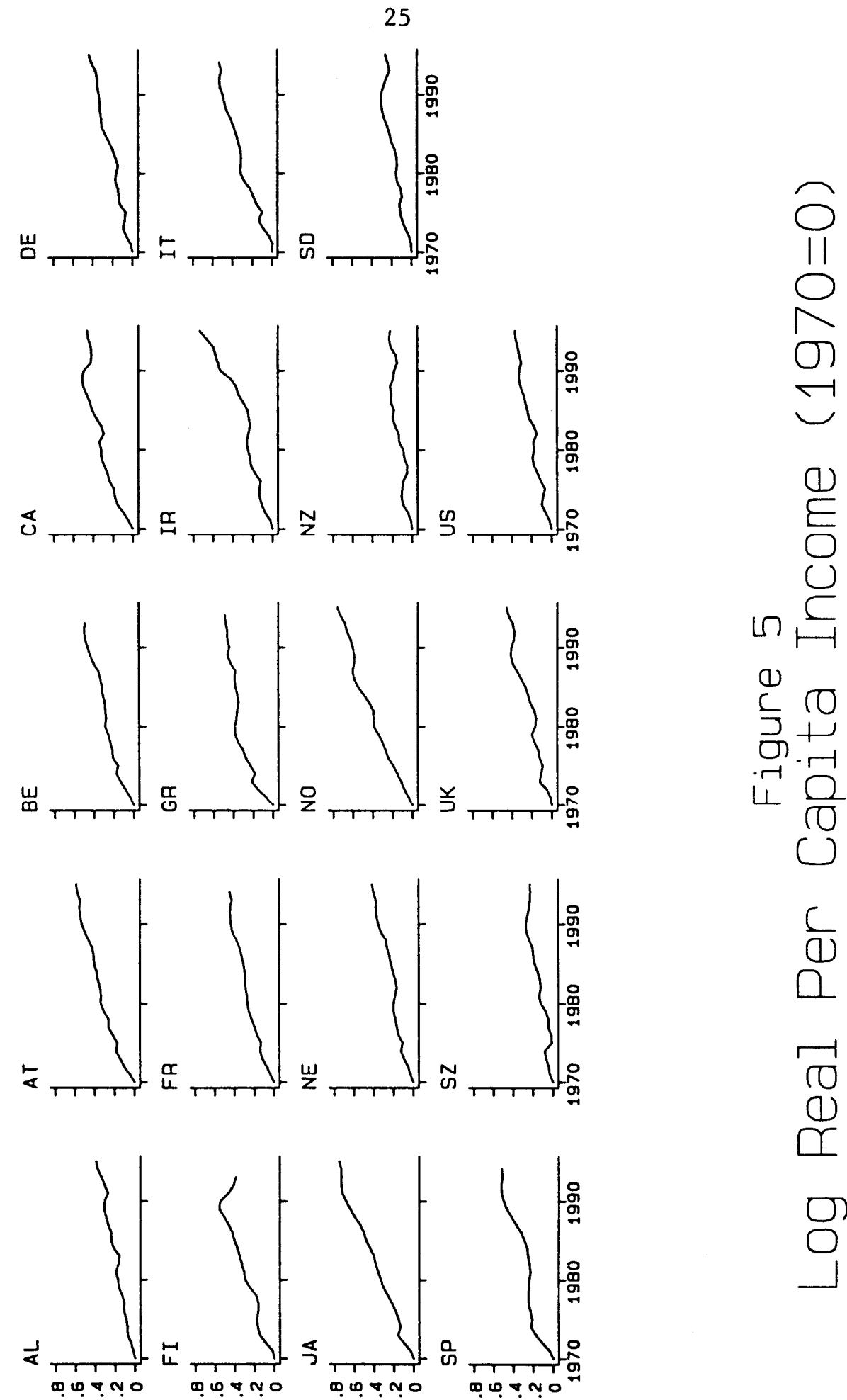

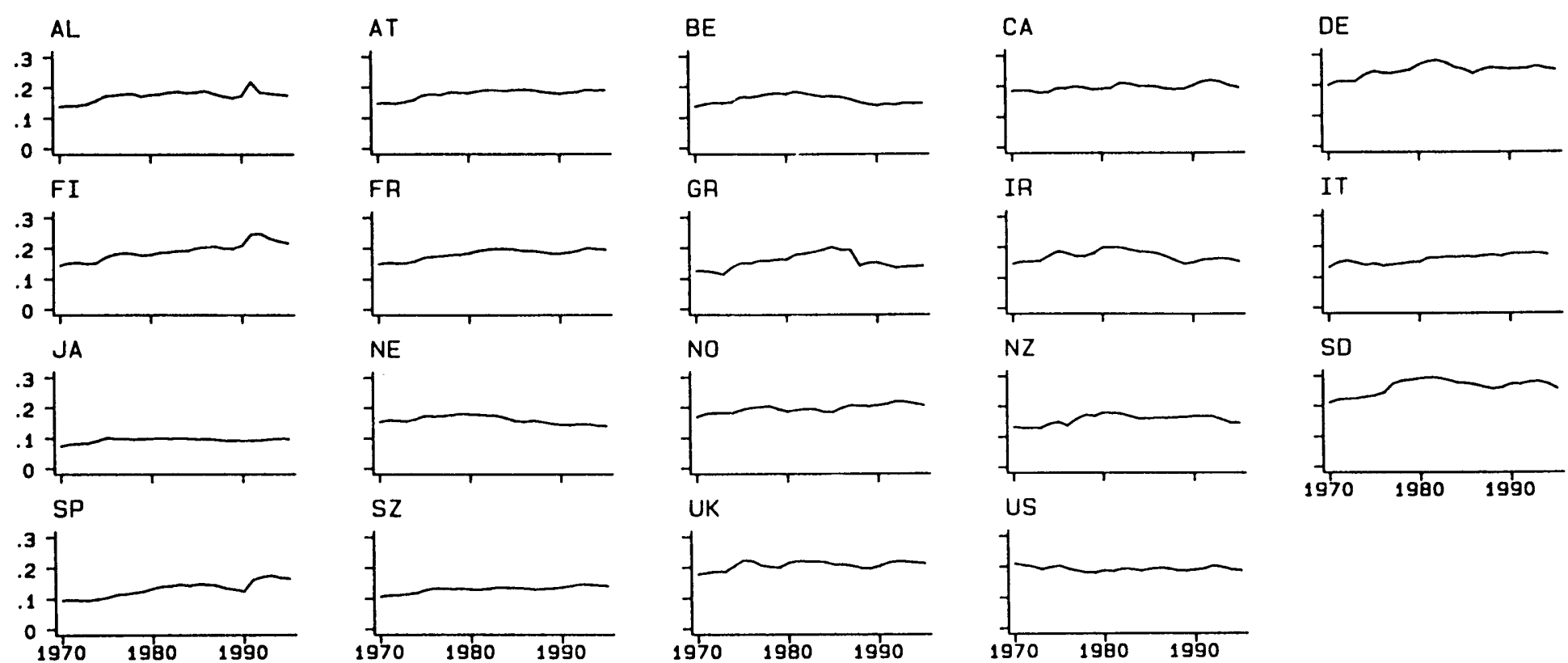

SD
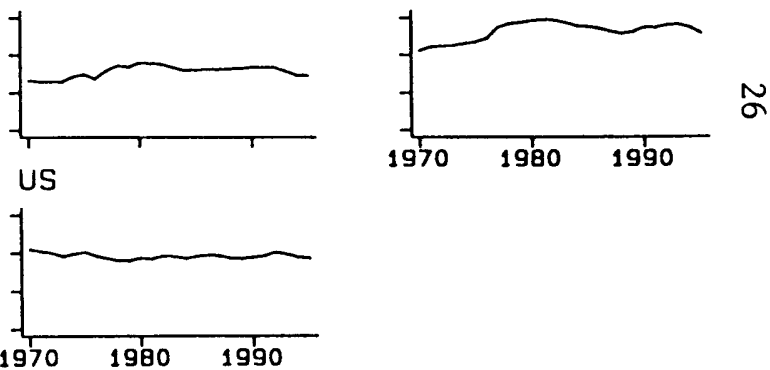

Figure 6 Government Share of GDP 


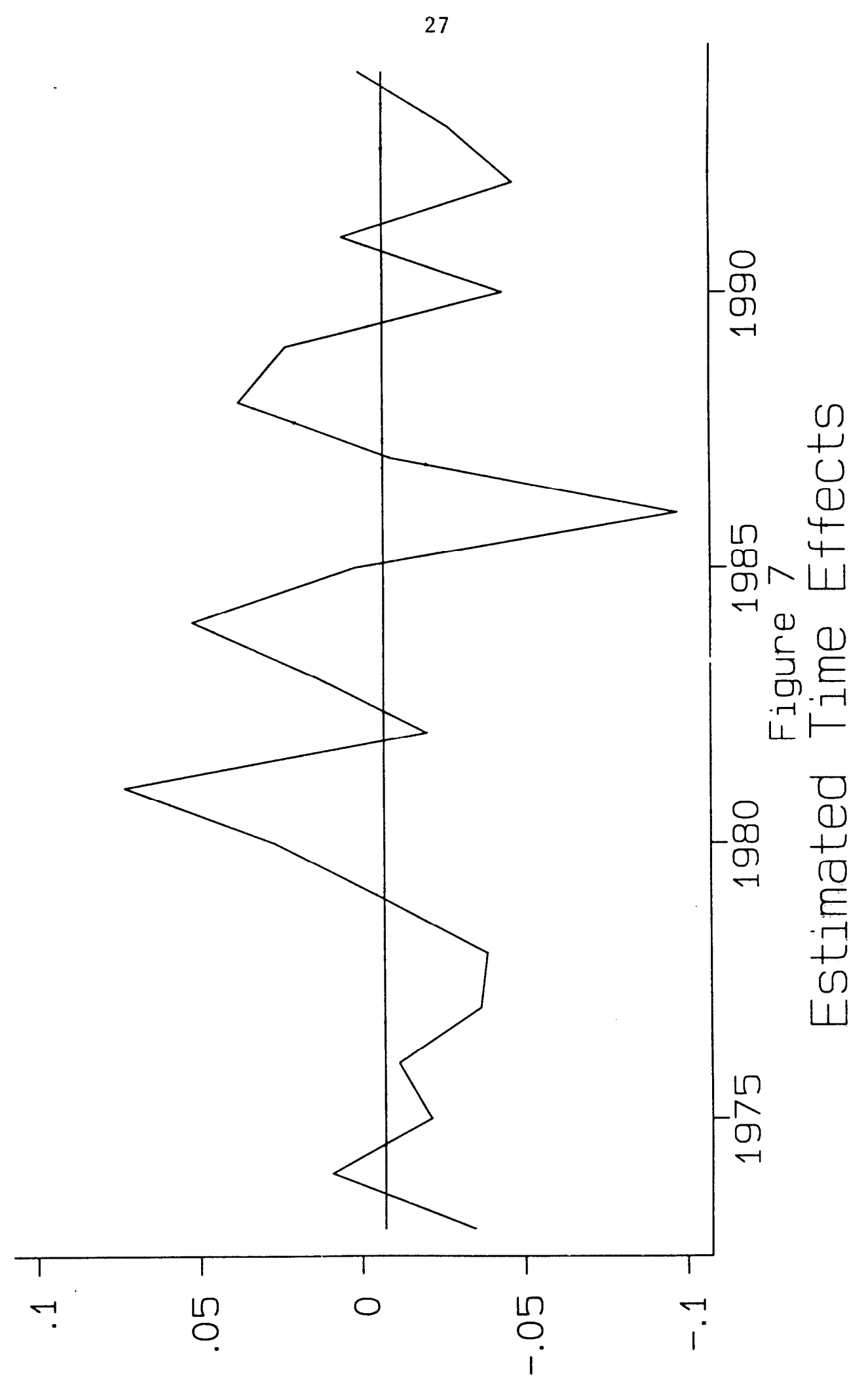



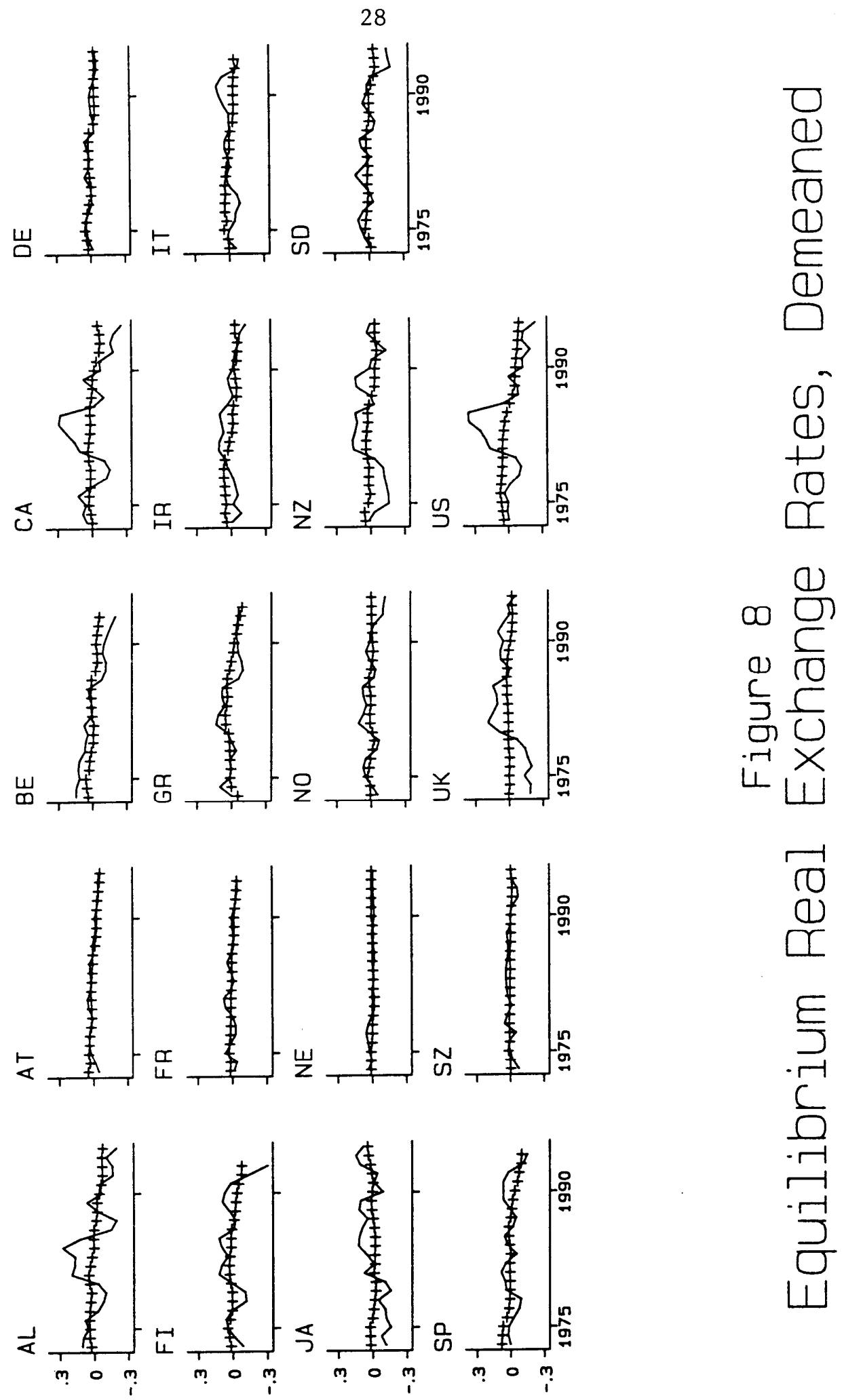


\section{International Finance Discussion Papers}

IFDP

Number
Titles

1996

$574 \quad$ Net Foreign Assets and Equilibrium Exchange Rates: Panel Evidence

573 Timing of Childbearing, Family Size and Economic Growth

572 Money, politics and the post-War business cycle

571 Implications of Economic Interdependence and Exchange Rate Policy on Endogenous Wage indexation Decisions

570 The Reaction of Exchange Rates and Interest Rates to News Releases

569 The Role of Credit in Post-Stabilization Consumption Booms

568 Hazards in Implementing a Monetary Conditions Index

567 Financial Innovation And The Speed of Adjustment of Money Demand: Evidence From Bolivia, Israel, And Venezuela

566 Long-Tem Evidence on the Tobin and Fisher Effects: A New Approach

Shaghil Ahmed John H. Rogers

565 Some Evidence on the Efficacy of the UK Inflation Targeting Regime: An Out-of-Sample Forecast Approach

564 The Use of the Parallel Market Rate as a Guide to Setting the Official Exchange Rate

Nita Ghei Steven B. Kamin

Country Fund Discounts and the Mexican Crisis of December 1994: Did Local Residents Tum Pessimistic Before International Investors?

Jeffrey A. Frankel Sergio L. Schmukler

Please address requests for copies to International Finance Discussion Papers, Division of Intermational Finance, Stop 24, Board of Govemors of the Federal Reserve System, Washington, DC 20551. Email: graym@frb.gov. Fax: (202)736-5638. 


\section{International Finance Discussion Papers}

IFDP

Number
Titles

1996
Eastem European Export Performance during the Transition

561

560

559

558

557

556

555

554

553

552

551

550
Inflation-Adjusted Potential Output

The Management of Financial Risks at German

Nonfinancial Fims: The Case of Metallgesellschaft

Broad Money Demand and Financial Liberalization in Greece

Stockholding Behavior of U.S. Households: Evidence from the 1983-89 Survey of Consumer Finances

Fim Size and the Impact of Profit-Margin Uncertainty on Investment: Do Financing Constraints Play a Role?

Regulation and the Cost of Capital in Japan: A Case Study

The Sovereignty Option: The Quebec Referendum and Market Views on the Canadian Dollar

Real Exchange Rates and Inflation in Exchange-Rate Based Stabilizations: An Empirical Examination

Macroeconomic State Variables as Determinants of Asset Price Covariances

The Tequila Effect: Theory and Evidence from Argentina

The Accumulation of Human Capital: Alternative Methods and Why They Matter

Alternatives in Human Capital Accumulation: Implications for Economic Growth
Author(s)

Nathan Sheets

Simona Boata

Jane T. Haltmaier

Allen B. Frankel

David E. Palmer

Neil R. Ericsson

Sunil Sharma

Carol C. Bertaut

Vivek Ghosal

Prakash Loungani

John Ammer

Michael S. Gibson

Michael P. Leahy

Charles P. Thomas

Steven B. Kamin

John Ammer

Martín Uribe

Murat F. Iyigun

Ann L. Owen

Murat F. Iyigun

Ann L. Owen 


\section{International Finance Discussion Papers}

IFDP

Number
Titles

1996

549 More Evidence on the Link between Bank

Health and Investment in Japan

$548 \quad$ The Syndrome of Exchange-Rate-Based Stabilization and the Uncertain Duration of Currency Pegs

547 German Unification: What Have We Learned from Multi-Country Models?

546 Returns to Scale in U.S. Production: Estimates and Implications

545 Mexico's Balance-of-Payments Crisis: A Chronicle of Death Foretold
The Twin Crises: The Causes of Banking and Balance-of-Payments Problems

High Real Interest Rates in the Aftemath of Disinflation: Is it a Lack of Credibility?

Precautionary Portfolio Behavior from a Life-Cycle Perspective

Using Options Prices to Infer PDF's for Asset Prices: An Application to Oil Prices During the Gulf Crisis

Monetary Policy in the End-Game to Exchange-Rate Based Stabilizations: The Case of Mexico

Comparing the Welfare Costs and the Initial Dynamics of Altemative Temporary Stabilization Policies

Long Memory in Inflation Expectations: Evidence from International Financial Markets
Michael S. Gibson

Enrique G. Mendoza Martin Uribe

Joseph E. Gagnon

Paul R. Masson

Warwick J. McKibbin

Susanto Basu

John G. Fernald

Guillemo A. Calvo

Graciela L. Kaminsky Carmen M. Reinhart

Graciela L. Kaminsky

Leonardo Leideman

Carol C. Bertaut

Michael Haliassos

William R. Melick

Charles P. Thomas

Steven B. Kamin

John H. Rogers

Martin Uribe

Joseph E. Gagnon 


\section{International Finance Discussion Papers}

IFDP

Number

537

536

535

534

533 $\underline{\text { Titles }}$

1996 $\underline{\text { Author(s) }}$

Allan D. Brunner

Chan Huh

Edwin M. Truman

Jeffrey A. Frankel Andrew K. Rose

Charles Engel

John H. Rogers 
Board of Governors of the Federal Reserve System

International Finance Discussion Papers

Number 574

December 1996

NET FOREIGN ASSETS AND EQUILIBRIUM EXCHANGE RATES:

PANEL EVIDENCE

Joseph E. Gagnon

NOTE: International Finance Discussion Papers are preliminary materials circulated to stimulate discussion and critical comment. References in publications to International Finance Discussion Papers (other than an acknowledgment that the writer has had access to unpublished material) should be cleared with the author or authors. 